\title{
Calcitonin Gene Products and the Kidney
}

\author{
A. Kurtz ${ }^{1}$, R. Muff ${ }^{2}$, and J.A. Fischer ${ }^{2}$ \\ ${ }^{1}$ Physiologic Institute, University of Zürich, Switzerland \\ ${ }^{2}$ Research Laboratory for Calcium Metabolism, Departments of Orthopedic Surgery and Medicine, University of Zürich, \\ Zürich, Switzerland
}

\begin{abstract}
Summary. Calcitonin gene-related peptide (CGRP) is localized in capsaicin-sensitive nerve fibres in the kidney and urogenital tract whereas calcitonin reaches the kidney through the general circulation. Systemic infusion of CGRP and perfusion of isolated rat kidney reduces vascular resistance, and increases renal blood flow and glomerular filtration. CGRP stimulates renin secretion in vivo and in vitro and inhibits contraction of isolated rat mesangial cells by angiotensin II. Calcitonin does not affect vascular resistance, renal blood flow and glomerular filtration, and is less potent in stimulating renin secretion, and does not alter contraction of isolated rat mesangial cells by angiotensin II. CGRP also exerts renal tubular effects brought about probably through interaction with calcitonin receptors. To this end, increased excretion of sodium and chloride, and stimulation of urinary flow are less pronounced with CGRP than with calcitonin. Calcitonin, moreover, stimulates the fractional urinary excretion of calcium and phosphate.
\end{abstract}

Key words: Calcitonin - Calcitonin gene-related peptide - Renovascular effects - Renotubular effects - Renin secretion

Alternative splicing of the initial calcitonin gene transcript results in the formation of two distinct messenger RNAs encoding the precursors of calcitonin and of calcitonin gene-related peptide (CGRP) $[2,26]$. In man and rat two calcitonin/ CGRP genes have been recognized [3, 40]. A pseudogene encoding a second calcitonin-like structure appears not to be expressed in man [40]. But CGRP-I (or $\alpha$ ) and -II (or $\beta$ ) have been identified in man and rat at the mRNA and peptide levels $[3,23,34]$.
Calcitonin and CGRP are single chain polypeptides consisting of 32 and 37 amino acids, respectively. They have in common amino-terminal ring structures linked by disulfide bridges and the carboxyltermini are amidated. In man, CGRP shares $16 \%$ structural homology with calcitonin whereas the homology between CGRP-I and -II is 92\% [13]. As a result, distinct receptors for calcitonin and CGRP have been identified [7, 11, 33, 42]. Human CGRP-I and -II, due to their high homology, crossreact almost completely, but subtle differences in the distribution of human CGRP-I and -II binding sites have been observed on receptor autoradiography of the human brain [22].

Calcitonin is predominantly synthesized and released from thyroid C-cells [15]. An important stimulator of calcitonin secretion is an increase in the extracellular calcium concentration [36]. Calcitonin can be considered as a hormone that reaches its target tissues via the circulation. Calcitonin lowers serum calcium levels through inhibition of bone resorption [37]. In the kidney, calcitonin stimulates the urinary excretion of calcium, phosphate, sodium, potassium and chloride, and enhances 1,25-dihydroxycholecalciferol production $[5,20,25,32]$.

CGRP is predominantly synthesized in the nervous system and is frequently found in peripheral nerves associated with blood vessels, but CGRP has also been identified in the normal human thyroid gland and in thyroid C-cells $[17,21,41]$. Much like the secretion of calcitonin, the release of CGRP from C-cells is stimulated by raised extracellular calcium concentrations [21]. In vivo serum levels of CGRP only minimally respond to changes of the extracellular calcium concentration and probably largely represent a spillover from the nervous system [6]. Plasma levels of CGRP are reduced in capsaicin-treated rats suggesting that cir- 
Table 1. Effects of CGRP and calcitonin in the kidney

\begin{tabular}{|c|c|c|}
\hline & CGRP & Calcitonin \\
\hline \multicolumn{3}{|l|}{ Relaxation } \\
\hline $\begin{array}{l}\text { Vascular smooth muscle cells } \\
\text { Mesangial cells } \\
\text { Ureter }\end{array}$ & $\begin{array}{l}++ \\
++ \\
++\end{array}$ & $\begin{array}{l}0 \\
0 \\
\text { ND }\end{array}$ \\
\hline Renal blood flow & $+t^{a}$ & 0 \\
\hline Glomerular filtration rate & $+{ }^{a}$ & 0 \\
\hline Renin secretion & ++ & 0 \\
\hline \multicolumn{3}{|l|}{ Tubular function } \\
\hline $\begin{array}{l}\text { Urinary flow } \\
\text { Fractional excretion }(\mathrm{Na}, \mathrm{Cl}) \\
\qquad\left(\mathrm{Ca}, \mathrm{PO}_{4}\right)\end{array}$ & $\begin{array}{l}+^{a} \\
+^{a} \\
0\end{array}$ & $\begin{array}{l}++ \\
++ \\
++\end{array}$ \\
\hline
\end{tabular}

${ }^{\text {a }}$ arterial pressure maintained; ND: not done

culating CGRP originates in part from the sensory nervous system [10]. The most prominent effects of CGRP are on the cardiovascular system where CGRP is a potent vasodilator and exerts positive chronotropic and inotropic actions on the heart $[8,14,16]$.

In the present review we have compared the renal effects of CGRP and calcitonin in vivo and in vitro (Table 1).

\section{Localization of CGRP in the Kidney and Urogenital Tract}

CGRP containing nerve fibres have been localized in kidneys of rat and guinea pigs $[29,35]$. Within the kidney the density of CGRP positive fibres is highest in the muscular layer of the renal pelvis. Immunoreactive nerve fibres are also recognized in the proximity of arteries and arterioles (including the juxtaglomerular apparatus) and in the periglomerular and peritubular space (Fig. 1). Reduction of CGRP containing rat renal nerve fibres following treatment with capsaicin inferres a sensory origin $[17,29]$. CGRP immunoreactive nerve fibres abolished with capsaicin are, moreover, abundant in the ureter and bladder [19].

\section{Renovascular Effects}

Effects of CGRP on renal blood flow and on renal vascular resistance have been examined in vivo in man, rats, dogs and rabbits. In anesthetized rats graded amounts of rat CGRP- $\alpha$ lead to a dosedependent fall of the renal vascular resistance and a simultanous increase of renal blood flow, which is associated with reduced mean arterial blood pressure [44]. In the dog renal blood flow and glo- merular filtration are increased [43]. In man and rabbits systemic infusion of CGRP reduces arterial pressure, and effective renal plasma and blood flow $[4,29]$. Since in vivo reduction of arterial pressure may reduce renal blood flow, effects of CGRP on the isolated rat kidney perfused at constant pressure have also been examined [30]. In this preparation rat CGRP- $\alpha$ reduces vascular resistance and blunts the vasoconstrictory effect of angiotensin II. In the isolated perfused rat kidney CGRP moreover increases the glomerular filtration rate and the glomerular filtration fraction and urinary flow [30].

In vitro CGRP blunts the contraction of mesangial cells obtained with angiotensin II [30]. Relaxation of mesangial cells by CGRP is consistent with the increased filtration fraction observed in vivo and in vitro. The effects of CGRP in isolated rat mesangial cells are presumably mediated by raised cAMP production, which was also observed in blood vessels $[12,27]$. cAMP production probably mediates the dilatory effect of CGRP in mesangial cells and presumably renal vascular smooth muscle cells. Calcitonin, on the other hand, does not affect cAMP formation in mesangial cells. Evidence was obtained that CGRP does not interfere with the calcium mobilization by angiotensin II in mesangial cells, suggesting that the dilatory effect of CGRP is caused by other mechanisms e.g. inactivation of the myosin light chain kinase [1, 30].

Taken together the results demonstrate that CGRP causes vasodilation of renal blood vessels and increases glomerular filtration. In the absence of calcitonin receptors in renal glomeruli and mesangial cells it would seem that CGRP exerts direct renovascular effects through interaction with specific receptors $[29,30,32,39]$.

\section{Renotubular Effects}

Calcitonin exerts pronounced tubular effects such as the enhancement of the urinary fractional excretion of sodium, chloride, potassium, calcium and phosphate, and stimulation of urinary flow $[5,20$, 32].

Tubular effects of systemic infusions of hCGRP-II have been examined in humans (Gnädinger et al., submitted for publication). The fractional excretion of sodium and chloride is raised, but less pronounced than with equimolar amounts of calcitonin. The urinary flow and the fractional excretion of calcium and phosphate are not affected by CGRP. Lowered excretion of sodium and potassium and reduction of urinary flow was 

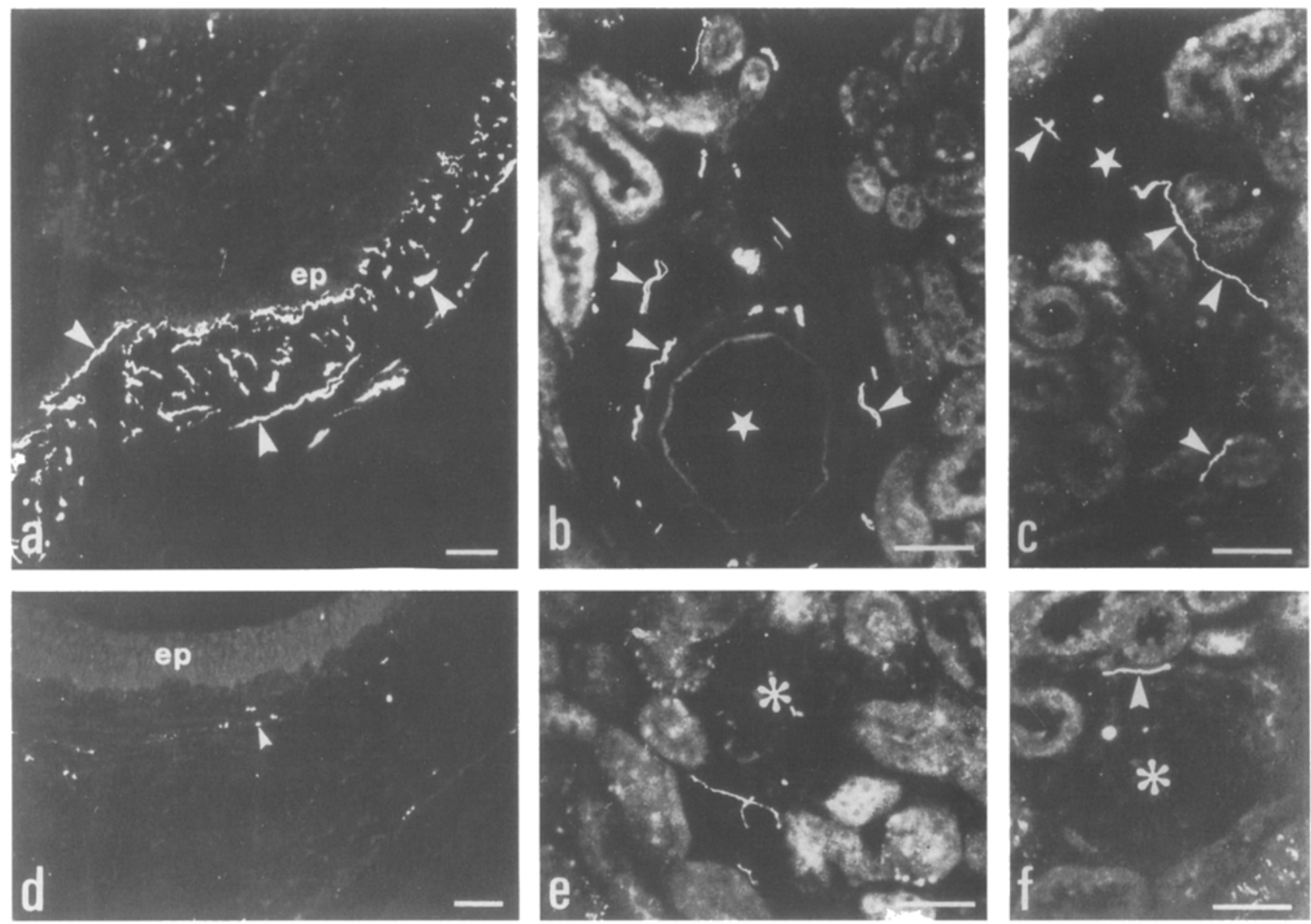

Fig. 1. Immunofluorescence micrographs from rat kidney sections after incubation with antiserum to rat CGRP $\alpha$. Pelvis region (a and $\mathbf{d}$ ), cortex region (b, $\mathbf{c}$, e, and $\mathbf{f}$ ). Control animals (a-c, e, and $\mathbf{f}$ ) and capsaicin-pretreated animals (d). A dense network of CGRP-immunoreactive nerve fibres is seen in the pelvis muscle and close to epithelium (ep) of the control rat, whereas most of the CGRP-immunoreactive nerve profiles disappeared after capsaicin treatment. CGRP-immunoreactive fibres (arrowheads) are also present around (b) small arteries $(\star)$, (c) among tubules, and (e and f) close to glomeruli (*) with associated arterioles. Bars, $50 \mu \mathrm{m}$. (From reference [29]; reproduced from the Journal of Clinical Investigation, 1988, vol 82, p 541 by copyright permission of the American Society of Clinical Investigation)

found with CGRP infusions in anesthetized rats, but mean arterial blood pressure was also reduced [44]. Interference of hypotension with tubular function seems probable. In the isolated rat kidney, however, perfused at constant pressure, enhancement of sodium excretion by CGRP and increased urinary flow are observed [30].

In cloned renal porcine tubular LLC-PK 1 cells calcitonin was more potent than CGRP in stimulating the production of cAMP and plasminogen activator [45]. Since calcitonin and CGRP exert similar tubular effects, it appears likely that CGRP interacts with calcitonin receptors localized on renal tubules [32].

\section{Renoendocrine Effects}

Renin and erythropoietin are released by the kidney and regulate blood pressure, extracellular vol- ume and erythropoiesis. Their regulation of secretion by CGRP has been examined in man and rats. Infusions of CGRP-II in man cause increased plasma renin activity which indicates stimulation of renal renin release [29]. At the same time the arterial blood pressure was reduced. It was therefore difficult to distinguish between a direct stimulatory action of CGRP on renal juxtaglomerular cells raising renin production and an indirect hypotensive effect also stimulating renin secretion.

In the isolated rat kidney, however, perfused at constant pressure $(100 \mathrm{~mm} \mathrm{Hg})$ rat CGRP- $\alpha$ causes a potent stimulation of renin secretion [30]. Furthermore, CGRP stimulates renin release from isolated renal juxtaglomerular cells [29]. Rat calcitonin is ineffective on juxtaglomerular cells, but the more potent salmon calcitonin stimulates renin release, albeit at concentrations that are 20 -fold higher than those of rat CGRP- $\alpha$. Salmon calcito- 
nin, moreover, stimulates renin secretion in rats, without concomitant changes of systemic arterial pressure [9]. The effects of rat CGRP- $\alpha$ are mediated through CAMP formation obtained in isolated renal juxtaglomerular cells with the same concentration dependence than renin secretion [29]. Since cAMP is an established stimulatory second messenger for renin secretion it appears likely that CGRP enhances renin secretion through activation of adenylate cyclase in juxtaglomerular cells.

Unlike renin that is stored in secretory granules, the renal secretion of erythropoietin is controlled by the rate of de novo synthesis which in turn depends on the transcriptional activity of the erythropoietin gene [28]. Therefore, a delay of $60 \mathrm{~min}$ between the onset of stimulation and initial rise of serum levels of erythropoietin is observed. Administration of hCGRP-I and -II in man in amounts stimulating renin secretion did not alter erythropoietin levels up to $120 \mathrm{~min}$ after the start of the CGRP infusions (Kurtz, unpublished). It seems therefore that CGRP does not affect renal erythropoietin formation.

\section{Renal Smooth Muscle}

The smooth muscle layer in the renal pelvis is densely innervated with CGRP immunoreactive nerve fibres, but possible effects of CGRP remain to be examined. CGRP inhibits the spontaneous activity of the smooth musculature of the ureter causing dilation [1 A, 24, 31]. Since the smooth muscle layer of the ureter originates from the renal pelvis it appears possible that CGRP also exerts a dilatory effect on the renal pelvis.

\section{Physiological Relevance of the Renal Effects of CGRP and Calcitonin}

The understanding of the physiological effects of CGRP is hampered by the lack of knowledge along which route CGRP comes into contact with its target cells. Since CGRP is localized in nerve fibres in the vicinity of blood vessels, glomeruli and renal tubules, CGRP is probably locally released from nerve fibres. Treatment with capsaicin released CGRP presumably originating from sensory nerve fibres in the kidney. Capsaicin also enhanced the release of CGRP in calcium-dependent manner from the rat spinal cord and the heart $[17,18$, 38]. Raised tension is a well established stimulator of afferent nerve fibres. To this end, increased intrapelvical volume and pressure enhance the tension of the smooth musculature of the pelvis and thus activate afferent nerve fibres. This may result in pain sensation, and presumably in the release of CGRP which in turn reduces the spontaneous activity of the renal pelvis causing dilation, and thus counteracts the painful contraction.

The possible role of CGRP released from nerve fibres present in the renal cortex is less evident. Increased interstitial pressure could activate the nerve fibres and cause release of CGRP. This may also explain why increased renal interstitial pressure is associated with stimulation of renin secretion.

Renal tubular effects such as the stimulation of the fractional urinary excretion of calcium, phosphate, sodium and potassium are presumably brought about through interaction with calcitonin receptors. Nevertheless, localized release of CGRP from nerve fibres may be physiologically as relevant as the interaction of calcitonin reaching the kidney tubules through the general circulation from the thyroid C-cells.

CGRP may be important for the fine regulation of kidney function. Depending from which nerves CGRP is released, the neuropeptide may affect the renal vasculature directly, and exert indirect effects via the renin/angiotensin system.

Acknowledgements: This study was supported by the Swiss National Science Foundation grants 3.8000 .86 and 3.924-0.87, and the Kanton of Zürich.

\section{References}

1. Adelstein RS (1983) Regulation of contractile proteins by phosphorylation. J Clin Invest 72:1863-1866

1A. Amann R, Skofitsch $G_{2}$ Lembeck F (1988) Species-related differences in the capsaicin-sensitive innervation of the rat and guinea-pig ureter. Naunyn-Schmiedeberg's Arch Pharmacol 338:407-410

2. Amara SG, Jonas V, Rosenfeld MG, Ong ES, Evans RM (1982) Alternative RNA processing in calcitonin gene expression generates mRNAs encoding different polypeptide products. Nature $298: 240-244$

3. Amara SG, Arriza JL, Leff SE, Swanson LW, Evans RM, Rosenfeld MG (1985) Expression in brain of a messenger RNA encoding a novel neuropeptide homologous to calcitonin-gene related peptide. Science 229:1094-1097

4. Bauerfeind P, Hof R, Hof A, Cucala M, Sigrist S, von Ritter C, Fischer JA, Blum AL (1989) Distinct effects of human calcitonin gene-related peptides I and II on gastric blood flow and acid secretion in anesthetized rabbits. Amer J Physiol 256:G145-G149

5. Bijvoet OLM, Van Der Sluys Veer J, De Vries HR, Van Koppen ATJ (1971) Natriuretic effect of calcitonin in man. New Engl J Med 284:681-688

6. Born W, Rink H, Beglinger C, Fischer JA (1989) Differential regulation of secretion by calcium of the common region peptide of the calcitonin gene, calcitonin and calcitonin gene-related peptide in man. Program 71st Ann Meeting Endocrine Soc (abstract) 
7. Bouizar Z, Fouchereau-Peron M, Taboulet J, Moukthar $S$, Milhaud G (1986) Purification and characterization of calcitonin receptors in rat kidney membranes by covalent cross-linking techniques. Europ J Biochem 155:141-147

8. Brain SD, Williams TJ, Tippins JR, Morris HR, MacIntyre $\mathrm{I}(1985)$ Calcitonin gene-related peptide is a potent vasodilator. Nature 313:54-56

9. Clementi G, Rapisarda E, Fiore CE, Prato A, Amico-Roxas M, Millia C, Bernardini R, Maugeri S, Scapagnini U (1986) Effects of salmon calcitonin on plasma renin activity and systolic blood pressure in the rat. Neurosci Lett 66:351-355

10. Diez-Guerra FJ, Zaidi M, Bevis P, MacIntyre I, Emson PC (1988) Evidence for release of calcitonin gene-related peptide and neurokinin A from sensory nerve endings in vivo. Neuroscience 25:839-846

11. Dotti-Sigrist S, Born W, Fischer JA (1988) Identification of a receptor for calcitonin gene-related peptides I and II in human cerebellum. Biochern Biophys Res Commun 151:1081-1087

12. Edvinsson L, Fredholm BB, Hamel E, Jansen I, Verrecchia C (1985) Perivascular peptides relax cerebral arteries concomitant with stimulation of cyclic adenosine monophosphate accumulation or release of an endothelium-derived relaxing factor in the rat. Neurosci Lett $58: 213-217$

13. Fischer IA, Born W (1987) Calcitonin gene products: evolution, expression and biological targets. Bone and Mineral $2: 347-359$

14. Fisher LA, Kikkawa DO, Rivier JE, Amara SG, Evans RM, Rosenfeld MG, Vale WW, Brown MR (1983) Stimulation of noradrenergic sympathetic outflow by calcitonin gene-related peptide. Nature 305:534-536

15. Foster GV, Baghdiantz A, Kumar MA, Slack E, Soliman HA, McIntyre (1964) Thyroid origin of calcitonin. Nature 202:1303-1305

16. Franco-Cereceda A, Gennari C, Nami R, Agnusdei D, Pernow J, Lundberg JM, Fischer JA (1987) Cardiovascular effects of calcitonin gene-related peptides $I$ and II in man. Circul Res 60:393-397

17. Franco-Cereceda A, Henke H, Lundberg IM, Petermann JB, Hökfelt T, Fischer JA (1987) Calcitonin gene-related peptide (CGRP) in capsaicin-sensitive substance P-immunoreactive sensory neurons in animals and man: Distribution and release by capsaicin. Peptides $8: 399-410$

18. Franco-Cereceda A, Lundberg JM, Saria A, Schreibmayer W, Tritthart HA (1988) Calcitonin gene-related peptide: release by capsaicin and prolongation of the action potential in the guinea-pig heart. Acta Physiol Scand 132:181-190

19. Ghatei MA, Gu J, Mulderry PK, Blank MA, Allen JM, Morrison JFB, Polak JM, Bloom SR (1985) Calcitonin gene-related peptide (CGRP) in the female rat urogenital tract. Peptides 6:809-815

20. Haas HG, Dambacher MA, Guncaga J, Lauffenburger T (1971) Renal effects of calcitonin and parathyroid extract in man. Studies in hypoparathyroidism. J Clin Invest $50: 2689-2702$

21. Haller-Brem S, Muff R, Petermann JB, Born W, Roos BA, Fischer JA (1987) Role of cytosolic free calcium concentration in the secretion of calcitonin gene-related peptide and calcitonin from medullary thyroid carcinoma cells. Endocrinology 121:1272-1277

22. Henke H, Sigrist S, Lang W, Schneider J, Fischer JA (1987) Comparison of binding sites for the calcitonin gene-related peptides I and II in man. Brain Res 410:404-408

23. Höppener JWM, Steenbergh PH, Slebos RJC, Visser A, Lips CJM, Jansz HS, Bechet JM, Lenoir GM, Born W, Haller-Brem S, Petermann JB, Fischer JA (1987) Expression of the second calcitonin/calcitonin gene-related peptide gene in Ewing sarcoma cell lines. J Clin Endocrinol Metab $64: 809-817$

24. Hua X-Y, Theodorsson-Norheim E, Lundberg JM, Kinn A-C, Hökfelt T, Cuello AC (1987) Co-localization of tachykinins and calcitonin gene-related peptide in capsaicinsensitive afferents in relation to motility effects on the human ureter in vitro. Neuroscience 23:693-703

25. Jaeger P, Jones W, Clemens TL, Hayslett JP (1986) Evidence that calcitonin stimulates 1,25-dihydroxyvitamin $\mathrm{D}$ production and intestinal absorption of calcium in vivo. J Clin Invest $78: 456-461$

26. Jonas V, Lin CR, Kawashima E, Semon D, Swanson LW, Mermod J-J, Evans RM, Rosenfeld MG (1985) Alternative RNA processing events in human calcitonin/calcitonin gene-related peptide gene expression. Proc Natl Acad Sci USA 82:1994-1998

27. Kubota M, Moseley JM, Butera L, Dusting GJ, MacDonald PS, Martin TJ (1985) Calcitonin gene-related peptide stimulates cyclic AMP formation in rat aortic smooth muscle cells. Biochem Biophys Res Commun 132:88-94

28. Kurtz A, Eckardt KU, Tannahill L, Bauer C (1988) Regulation of erythropoietin production. Contr Nephrol 66:1-16

29. Kurtz A, Muff R, Born W, Lundberg JM, Millberg B-I, Gnädinger MP, Uehlinger DE, Weidmann $P$, Hökfelt $T$, Fischer JA (1988) Calcitonin gene-related peptide is a stimulator of renin secretion. $J$ Clin Invest $82: 538-543$

30. Kurtz A, Schurek HJ, Jelkmann W, Muff R, Lipp P, Fischer JA, Bauer C (1989) The renal mesangium is a target for calcitonin gene-related peptide. Kidney Intl (in press)

31. Maggi CA, Giuliani S, Santicioli P, Abelli L, Meli A (1987) Visceromotor responses to calcitonin gene-related peptide (CGRP) in the rat lower urinary tract: evidence for a transmitter role in the capsaicin-sensitive nerves of the ureter. Europ J Pharmacol 143:73-82

32. Morel F (1983) Regulation of kidney functions by hormones: A new approach. In: Greep RO (ed) Recent Progress in Hormone Research, vol 39, Academic Press, New York, pp 271-304

33. Moseley JM, Findlay DM, Martin TJ, Gormann JJ (1982) Covalent crosslinking of a photoactive derivative of calcitonin to human breast cancer cell receptors. $J$ Biol Chem 257:5846-5851

34. Petermann JB, Born W, Chang J-Y, Fischer JA (1987) Identification in the human central nervous system, pituitary, and thyroid of a novel calcitonin gene-related peptide, and partial amino acid sequence in the spinal cord. $J$ Biol Chem $262: 542-545$

35. Reinecke M, Forsmann WG (1988) Neuropeptide (neuropeptide $\mathrm{Y}$, neurotensin, vasoactive intestinal polypeptide, substance $P$, calcitonin gene-related peptide, somatostatin) immunohistochemistry and ultrastructure of renal nerves. Histochemistry 89:1-9

36. Roos BA, Bundy LL, Miller EA, Deftos LJ (1975) Calcitonin secretion by monolayer cultures of human C-cells from medullary thyroid carcinoma. Endocrinology 97:39-45

37. Roos BA, Fischer JA, Pignat W, Alander CB, Raisz LG (1986) Evaluation of the in vivo and in vitro calcium-regulating actions of noncalcitonin peptides produced via calcitonin gene expression. Endocrinology 118:46-51

38. Saria A, Gamse R, Petermann JB, Fischer JA, Theodorsson-Norhein E, Lundberg JM (1986) Simultaneous release of several tachykinins and calcitonin gene-related peptide from rat spinal cord slices. Neurosci Lett 63:310-314

39. Sexton PM, Adam WR, Moseley JM, Martin TJ, Mendelsohn FAO (1987) Localization and characterization of renal calcitonin receptors by in vitro autoradiography. Kidney Intl $32: 862-868$ 
40. Steenbergh PH, Höppener JWM, Zandberg J, Visser A, Lips CJM, Jansz HS (1986) Structure and expression of human calcitonin/CGRP genes. FEBS Lett 209:97-103

41. Tschopp FA, Tobler PH, Fischer JA (1984) Calcitonin generelated peptide in the human thyroid, pituitary and brain. Mol Cell Endocrinol 36:53-57

42. Tschopp FA, Henke H, Petermann JB, Tobler PH, Janzer R, Hökfelt T, Lundberg JM, Cuello C, Fischer JA (1985) Calcitonin gene-related peptide and its binding sites in the human central nervous system and pituitary. Proc Natl Acad Sci USA 82:248-252

43. Villarreal D, Freeman RH, Verburg KM, Brands MW (1988) Renal hemodynamic response to intrarenal infusion of calcitonin gene-related peptide in dogs. Peptides 9:1129-1135
44. Villareal D, Freeman RH, Verburg KM, Brands MW (1988) Effects of calcitonin gene-related peptide on renal blood flow in the rat. Proc Soc Exp Biol Med 188:316-322

45. Wohlwend A, Malmström K, Henke H, Murer H, Vassalli J-D, Fischer JA (1985) Calcitonin and calcitonin gene-related peptide interact with the same receptor in cultured LLC-PK 1 kidney cells. Biochem Biophys Res Commun $131: 537-542$

Prof. J.A. Fischer

Klinik Balgrist

Forchstrasse 340

CH-8008 Zürich

Switzerland 